\title{
An Extraordinary Leader: Queen Christina
}

\author{
Zaliha İnci Karabacak \\ Assist. Prof. Dr./ TOBB ETÜ, Visual Communication Design Department \\ inci_yildirim@yahoo.com
}

\section{Doi:10.5901/mjss.2015.v6n2s5p376}

\begin{abstract}
Queen Christina (Maria Christina Alexandra) (1626-1689) who marked the 17th century's history of Sweden emerges as a major political actor. She has reached to this period not only with her activities but also with her appearance, her free soul and her extraordinary character. Owing to be the person who would assume responsibility of a country in the near future, she had grown more like a man than a woman. In another words, her parent's training style shaped her gender. She never married and avoided living according to customs. Also she preferred to wear men's clothes. Hereby, she was considered as an hermaphrodite by some people. This study examines the Queen Cristina's reflection in popular culture. With this purpose, literature review method is used in the study. The research results indicate that there are strong links (with many aspects; literature, art, cinema, cultural events, spor activities etc. ) between Queen Christina and popular culture. Queen Christina was the founder of the world's oldest newspaper called "Post och Inrikes Tidningar" (PolT-Post and Domestic Times). The newspaper was founded in 1645. She was interested in philosophy, science, religion and art. Queen Christina was in close contact with fine arts in Rome where she spent the last days of her life. Her sophisticated character has being source of inspiration for many works of art (films, paintings, photographies etc. ). For example, there is a photo called "Christina of Sweden-The Androgynous Queen" as a part of "The Regal Twelve" series by Alexia Sinclair. Also, a film called "Queen Christina" was directed by Rouben Mamoulian in 1933. Swedish-born actress Greta Garbo starred in the film with John Gilbert. The museum called "Livrustkammaren" (The Royal Armoury) is the oldest museum in Sweden. The museum collection has many pieces about Queen Christina. As a result, it is observed that Queen Christina has significant contribution to popular culture from past to present.
\end{abstract}

Keywords: Queen Christina, Gender, Leader, Popular Culture

\section{Introduction}

Queen Christina ${ }^{2}$ is known not only with her royal identity but also with her intellectual personality, with her actions, with her different appearance in the world history. She was daughter of King Gustavus II Adolphus and Maria Eleonora. King Gustavus II Adolphus is an also very important leader.

Gustavus II Adolphus was known as "The Golden King" and "The Lion of the North". According to a prophecy made by Paracelsus ${ }^{3}$ in 1549; a series of worldwide disasters that he had foretold would only end when a Golden Lion came from the north to defeat the Eagle. The Thirty Years' War which broke out in 1618 is expressed as the begining of the disasters. The Catholic Emperor of Germany (his emblem was the black eagle) went on the rampage in Protestant Germany. Gustavus II Adolphus came to the rescue in 1630 (Brzezinski, 2004: 3). Gustavus II Adolphus died in late 1632 in the battle of Lützen (Goes, 2013: 301).

Christina was born on December 8, 1626 as a member of Swedish royal family. Her family hoped for a boy who would become King. So, Maria Eleonora disdained her daughter. Kristina was insisted to be provided with the princely education that would have been accorded a male heir by King Gustavus (http: //www. iep. utm. edu/wasa/). Christina began to participate in the national government and attend meetings of the cabinet of ministers in 1640 . She was formally crowned as monarch of Sweden in 1644. Queen Kristina began a correspondence, about the nature of love, the question of the universe's infinity, and the nature of the sovereign good, with Descartes in 1646. Queen Kristina played a crucial role in ending the Thirty Years' War (in 1648) with the Treaty of Westphalia. Christina abdicated the Swedish throne in June 1654 (http: //www. iep. utm. edu/wasa/\#H1).

After her abdication at the age of twenty-seven, Christina went to Rome. She supported some musicians and artists like Scarlatti, Corelli and Giovanni Bernini (Cavendish, 2004: 54). In Rome, Christina continued to use masculinized strategies. For example, she reportedly wore male clothing most of the times she appeared in public (Lucca, 2010: 387). After abdication, she left Sweden with masculine attire under the name of Count Dohna. In Rome she received permission to wearing men's clothes as she chose (Bullough, 1993: 97). Before finally settling in Rome until her 
death in 1689 she had travelled in Germany, the Low countries and France. She collected very special works of art (pictures and sculpture) (Haskell, 1966: 494).

Christina converted to Catholicism in 1655. Due to this conversion she was greeted by Pope Alexander VII with lavish ceremonies in Rome (http: //www. iep. utm. edu/wasa/). According as converting to Roman Catholicism, Christina is one of four women to be buried in the crypt of St. Peter's Basilica alongside the remains of the popes (http: //www. unisa. edu. au/global/samstag/exhibitions/2009/documents/alexiasinclair_roomnotes. pdf).

According to the 17th century text as well as the brief passages from various web pages Nivre (2010: 54) emphasizes that Queen Christina is commonly used as a model to define historical and cultural criteria for the identification of sex and gender.

Contrary to common belief that Christina was lesbian, now she is believed to be bisexual. Because she had many loves both female (Ebba Sparre and Angela) and male (her cousin Karl, the courtier Magnus De la Gardie and Cardinal Azzolino) in her life. Although Christina is assumed to have been a virgin until her death, she is said to had numerous infatuations and affairs. Many people think that Christina's bisexualty and her constant behavior as a man stems from her upbringing. Because, as an infant Christina was told to be raised as a prince by her father (http: //royalwomen. tripod. com/id4. html). Christina's body was exhumed for testing in 1965 to determine whether she had signs of hermaphroditism. However the results were inconclusive (http: //www. unisa. edu. au/global/samstag/exhibitions/2009/ documentsalexiasinclair_roomnotes. pdf).

The short life story of Queen Christina above, reflects her colorful personality. As well as not being a member of an ordinary family she wasn't grown as an ordinary girl. Christina was grown like a boy more than a girl. This seems to be the turning point of her life and her gender. She was dead in 1689. But, her impact on culture keeps going. Her politic career, her gender, her cultural activities etc. are reflected in popular culture in many ways.

Popular culture seems to be a controversial area which contains different perspectives. The six definition of popular culture which are given by Storey (2009: 5-12) can be summarized as follows:

1) The culture that is widely favoured or well liked by many people (It can be examined by sales of books, CDs, DVDs or records at concerts, sporting events, festivals etc. ).

2) The culture that is left over after we have decided what is high culture (Inferior culture).

3) The culture is as "mass culture"

4) The culture that originates from "the people". "Authentic" culture of "the people". (Folk culture)

5) The culture from the perspective of "hegemony theory" of Antonio Gramsci.

6) The culture that informed by recent thinking around the debate on postmodernism.

Owing to development of industrial system, which based on factory, production economy evolved in 19th century. Railroad lines in Europe and USA, The Brooklyn Bridge, Eiffel Tower, canned food, cotton clothing, the department store etc. are some indicators the new economy (Betts, 2004: 9). Storey (2009: 12) emphasizes that popular culture is definitely a culture which only emerged following industrialization and urbanization.

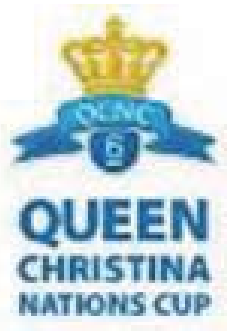

Figure 1. Queen Christina Nations Cup's Logo

Erdoğan and Alemdar (2005: 39) assert that the popular was being determined and defined by folk with their daily practices in the past. But today, the popular is being determined and defined by industries (fashion, soda, toy, tourism, culture, entertainment) that selling goods and consciousness. Mutlu (2006: 27) emphasizes that popular culture contains both works of high culture art like Mona Lisa (which is visited by many people from every segment of society) and popular culture products like film posters, cartoons, stardom's clothes and accessories which are incorporated into the tradition of museum.

There are many sources of popular culture. But the major is the mass media, particularly popular music, television, film, radio, books, video games and the internet (https: //philosophynow. org/issues/64/Pop_Culture_An_Overview). 
Popular culture seems to usually use the major figures of everyday life. So renowned historical figures like Queen Christina have become the subjects of several popular culture products. In this context, the study aims to follow Queen Christina's reflection in popular culture.

\section{Methodology}

In this study, literature review method is used. At the begining of the research, resources and documents that relate to the subject were detected. In this process; books, academic articles, newspapers, biographies, literary works in libraries and internet resources were examined. Also, the study which was done in the context of popular culture made necessary to examine visual sources like films, photos, book covers, posters and postage stamps.

According to literatur review, both visual and written sources helped to examine the subject in different views. The research revealed Queen Christina's multifaceted relationship with popular culture as a leader, a woman, an intellectual etc.

The literature review provided a historical perspective for the research. The research subject was examined through both current resources and historical sources by literature review. In this regard, examples that took place in the study were varied through different resources as books, articles, poems, stamps, films, newspapers, biographies, paintings etc. Also internet resources made significant contributions to study.

\section{Analysis and Discussion}

Queen Christina is reflected by several ways in popular culture. Literatur review about Queen Christina which was made in the context of popular culture refered to the various events, works of art, everyday products, written and visual works etc.

The Project "the European Culture Initiative, Queen Christina of Sweden, the European" which follows the path of Queen Christina through Europe after her abdication, has concerts, seminars and other events during 2014-15 in nine different cities in Austria, Belgium, France, Italy and Sweden. The Queen Christina Project (The QC Project) is held with cooperation between cultural institutions in Sweden, France, Italy and Austria. Also it's supported by the Culture Programme of European Union as well as educational and research institutions, national art councils, foundations corporations, associations, individuals in four countries (http: //queenchristina. eu/the-qc-project/). The project called "the European Culture Initiative, Queen Christina of Sweden, the European" has different popular culture activities like concerts, seminars. The project provides an important contribution to present Swedish history to the other countries as well as to introduce the Queen to new generation.

Sport is representing a primary source of media spectacle in contemporary popular culture (Barron, 2012: 106). Boyle and Haynes (2009: 2) point out ties between sport and media as two great forces of twentieth-century popular culture have never been closer.

The first Queen Christina Nations Cup (QCNC) (See: Fig-1) was hosted by the United States Puget Sound Fleet in 2003 (http: //old. portmadisonyc. org/wp-content/uploads/2010/09/qcnc-story. pdf). QCNC which is an sailing competition between six meter sailors has been held in many countries since 2003. Sport as a great popular force of popular culture appeals to broad audiences. This situation increases the effects of competitions like Queen Christina Nations Cup (QCNC).

Queen Christina is used as a character in literature by writers. "Cristina and Monaldeschi" is a poem which was probably written in the late summer or autumn of 1882 at St. Pierre de Chartreuse by Robert Browning. In the poem, Cristina refers to Queen Christina of Sweden (Browning, 2007: 265).

"Christine ou Stockholm, Fontainebleau et Rome" was written by Alexandre Dumas in 1830. It was staged at "Théatre Royal de L'odéon" in Paris. Mademoiselle George strarred in the role of Queen Christina (See: Fig-2) (Dumas, 1830). 


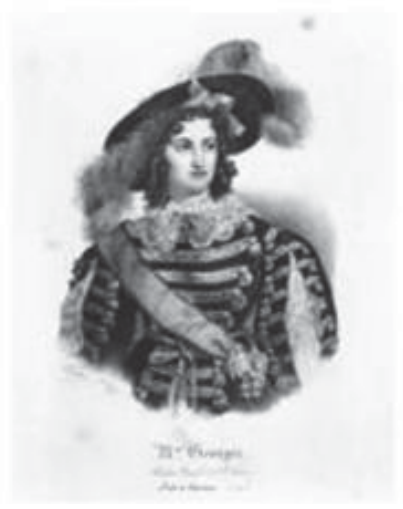

Figure 2: Mademoiselle George in the role of Queen Christina

Madeleine de Scudery gave Queen Christina the role of Cleobuline in her roman which is called Artamene, ou le Grand Cyrus (See: Fig-3) (Waters, 1994: 42). Madeleine de Scudery (1607-1701) is a prominent novelist who composed a series of dialogues dealing with philosophical issues. Her works fall into several varied genres; the novel, the novella, the dialogue, the oration, and the letter (http: //plato. stanford. edu/entries/madeleine-scudery/\#Wor).

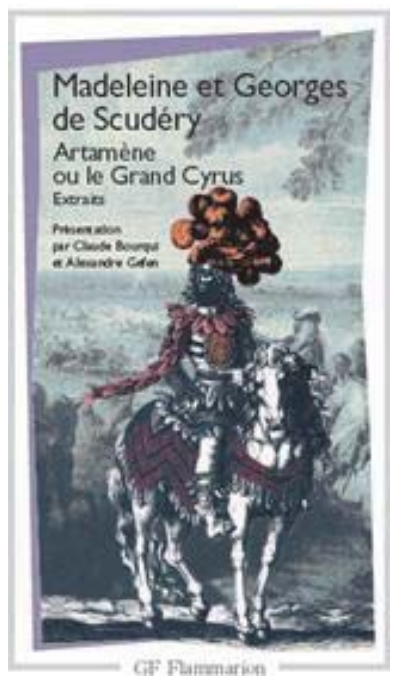

Figure 3: Artamene ou le Grand Cyrus-Book Cover

Museum as a cultural space is the bridge between past and future. Museums carry historical values (leaders, artists, works of art, documents etc. ) today. Queen Christina takes part with works of art, in which she was used as a model, in museums like "National Museum" (Stockholm), "Museo del Prado" (Madrid). Also her personal belongings, her costumes, her documents are exhibited in "Livrustkammaren" (The Royal Armoury- Stockholm).

One hundred original documents from the "Vatican Secret Archives" displayed in the halls of Capitoline Museum (Rome) between 29/02-09/09/2012 for the first time (http://en.museicapitolini.org/mostre_ed_eventi/mostre/ lux_in_arcana_I_archivio_segreto_vaticano_si_rivela). One of these original documents was "the abdication letter of Queen Christina of Sweden" (http://www.telegraph.co.uk/news/worldnews/europe/vaticancityandholysee/9111168/ Vatican-Secret-Archives-reveal-abdication-letter-of-hermaphrodite-Swedish-queen. html).

Photography was a major player in establishing and confirming the scientific and political power of the historical archive (Wolthers, 2013: 157). Since the late 60s, when nostalgia began to be profitable, popular culture classics have been usually revived in modernized forms (Gans, 2008: 33).

Alexia Sinclair is an Australian Artist and Photographer. Her celebrated series called "The Regal Twelve" portrays histrorical Queens (Isabella of Spain, Elizabeth I, Marie Antoinette, Cleopatra etc. ) (https: //alexiasinclair. com/about). 
"Christina of Sweden-The Androgynous Queen" (See: Fig-4) is a part of "The Regal Twelve" series. According to photo, Christina is huntress and protectress. She wears a mask which represents other faces or realities and alludes to Christina's cross gender through the two faces of one Queen (https: //alexiasinclair. com/collections/the-regaltwelve\#christina-of-sweden-description).

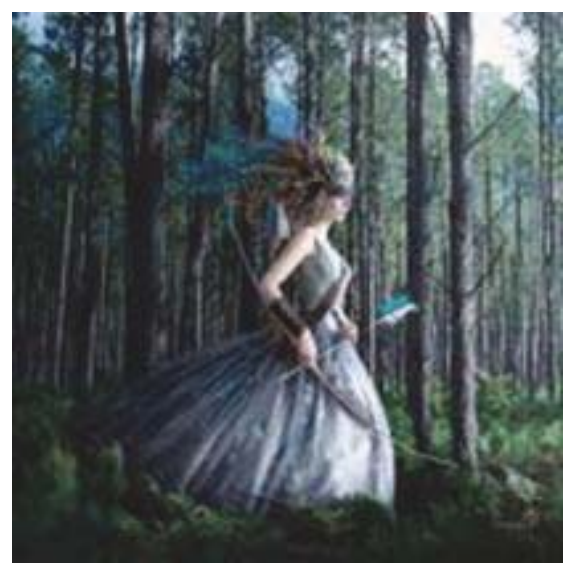

Figure 4: "Christina of Sweden-The Androgynous Queen" by Alexia Sinclair

Since the late 1700s; urbanization, industrialization, the mass media and the continuous growth in technology have all been significant factors in the formation of popular culture. Their influence on popular culture continues today (https: //philosophynow. org/issues/64/Pop_Culture_An_Overview).

Newspapers are important sources in terms of popular culture. Centuries ago, Queen Christina made a significant contribution to the development of today's press and popular culture.

The Post och Inrikes Tidningar (PolT-Post and Domestic Times), which is regarded as the world's oldest newspaper, was founded in 1645 by Queen Christina. Queen Christina and Axel Oxenstierna (Christina's chancellor) started the paper in 1645. PolT has become available only on the Internet since 1 January 2007. The newspaper remains the official news organ of the government, a role enshrined in Swedish law as it has been since 17th century (http: //www. washingtontimes. com/news/2007/jan/28/20070128-104107-2575r/). After Swedish Academy (who is the owner of PolT since 1791) had granted the publishing rights to Bolagsverket. PolT has transformed from a paper edition to a web service since 1 January 2007 with the name of "Posttidningen and Inrikes Tidningar" by Bolagsverket (https: //poit. bolagsverket. se/poit/PublikOmTjansten. do?method=redirect\&forward=main. omtjansten. inenglish).

Child (2005: 136) highlights postage stamps can be seen as icons of popular culture according to his research on Latin American postage stamps. Because, he represents that stamps are the products of government and the icons are seen and handled repeatedly by large numbers of people.

Considering her role in the establishment of the Finnish Postal System and as the Founder and Patron of the University of Helsinki, Queen Christina featured on some commemorative Finish stamps. Christina first issued standardised postal tariffs in 1638. For celebrating 300 years of the Finnish Postal System a set of commemorative stamps (See: Fig-5) issued in 1938. Also the 350th Anniversary of the University of Helsinki a commemorative stamp (See: Fig-6), on which Queen Christina took part, issued in 1990 (http: //www. vam. ac. uk/blog/creating-new-europe1600-1800-galleries/born-on-this-day-queen-christina-of-sweden).

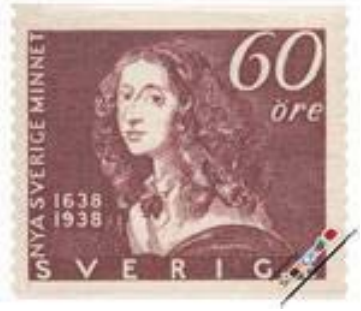

Figure 5: A commemorative stamp for celebrating 300 years of the Finnish Postal System 


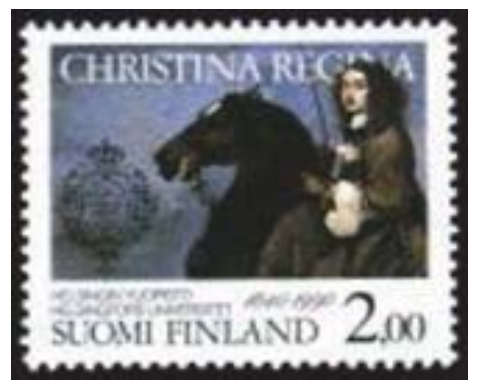

Figure 6: A commemorative stamp for the 350th Anniversary of the University of Helsinki

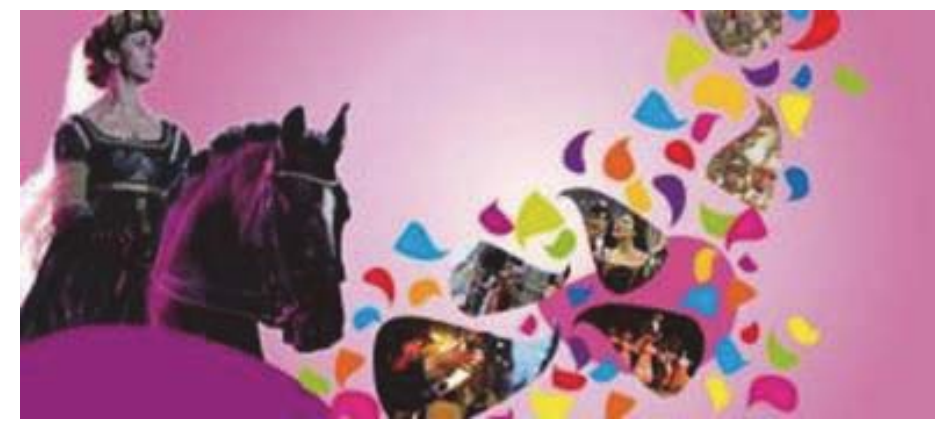

Figure 7: Image of $7^{\text {th }}$ edition of Roman Carnival 2015 dedicated to Christina, Queen of Sweden

It's claimed that, the pop culture serves the same kinds of social functions as did the medieval carnivals, by Mikhail Bakhtin (Danesi, 2008: 59). Carnival is a ceremony which has no distinction between audience and carnival performers. Everyone is an active participant in the carnival (Bakhtin, 2001: 238). Today the tradition of Carnival seems to continue by modern ways in many countries of world (Rio de Janerio, Venice, Munich etc. )

The 7th edition of Roman Carnival (See: Fig-7) which took place between 7-17 February 2015 dedicated to Queen Christina of Sweden on the occasion of the 360th anniversary of her entry into the capital (http: //www. romecentral. com/carnevale-romano-2015-roma-sfilate-e-feste-maschera/?lang=en). When Christina lived in Rome, the city's Carnival was more famous than Venice's. Also it was one of the most renown all over Europe. The Carnival was bound to take place for two more centuries until 1871 when it was abolished due to security problems. In 2015, the Carnival was decided to reborn with 7th edition of it's. It had many events which dedicated to Christina like a baroque music concert, a history talk, an academic seminar, a photography exhibition, the ancient costume party (http: //www. buzzinrome. com/2015/02/06/rome-dedicates-the-2015-carnival-to-christina-queen-of-sweden/).

According to Walter Benjamin's view that reproduction (by photography and film) disrupted the aura of art, Weaver (2009: 31) expresses: "Art was open to the consumption of the "masses" ushering in the beginnig of popular culture and the end of high art."

Today, famous works of art not only stay in museums but also take part in our everyday life as accesories. These works of art are used as a part of popular culture. Queen Christina, as an important historical figure, is also used with her portrait on many accesories like watches (See: Fig-8) and brooches (See: Fig-9)

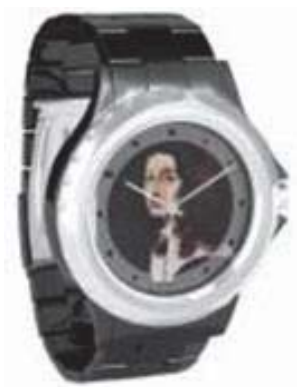

Figure 8: Woman Watch with Queen Christina's Portrait (that was made by Sébastien Bourdon) 


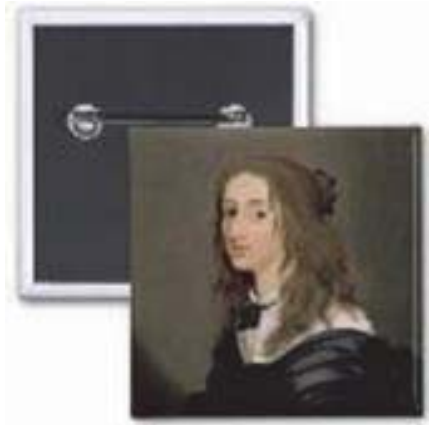

Figure 9: A Brooche with Queen Christina's Portrait (that was made by Sébastien Bourdon)

Queen Christina as a famous historical figure inspired many writers. So there is an extensive literature of books which were written about Queen Christina. Some of these can be listed as follows: "Queen Christina of Sweden" (Hardinge, 1880), "Queen Christina" (Masson, 1974), "Outrageous Queen: Biography of Christina of Sweden" (Cartland, 1974), "Christina Queen of Sweden: The Restless Life of a European Eccentric" (Buckley, 2005), "Kristina: The Girl King, Sweden, 1638 (The Royal Diaries)" (Meyer, 2003), "Queen Christina of Sweden (Queens and Princesses)" (Mattern, 2009).

Popular culture affects film industry. Tracer events and figures of world history are preferred as the subject of films. There are many films which based on; wars, leaders, scientists, politicians, victories etc.

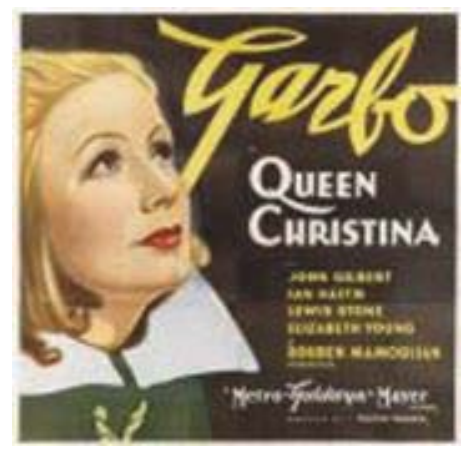

Figure 10: "Queen Christina"-Movie Poster-1933

"Queen Christina" is a film (See: Fig-10) in which Greta Garbo (See: Fig-11) plays as Queen Christina. Co-star is John Gilbert, who acts Don Antonio, an emissary from the King of Spain. The film was based on a story by Salka Vierted and Margaret P. Levino. It was directed by Rouben Mamoulian in $1933^{1}$

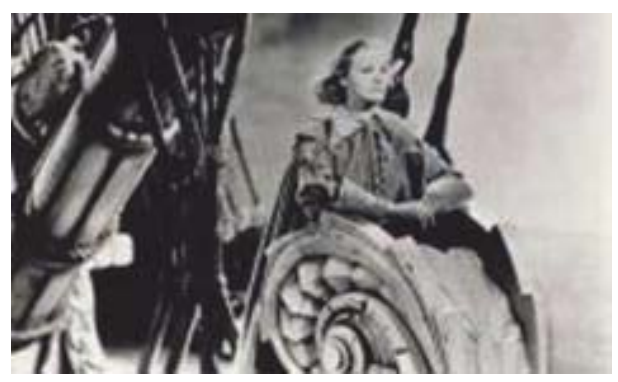

Figure 11: A Scene from "Queen Christina"- Greta Garbo as Queen Christina

Greta Garbo (1905-1990) is a Swedish film star. She was born in Stockholm as Greta Lovisa Gustafsson (Scobbie, 2006:

1 (http: //www. nytimes. com/movie/review?res=9802E1D91531E333A25754C2A9649D946294D6CF). 
73). Giving the leading part to Garbo, who was born in the same territory with Queen Christina, strenghthens the impact of the film as a popular culture product.

\section{Conclusion}

Popular culture and it's products surrounds the everyday life. Major historical figures as artists, politicians, leaders, scientists etc. are becoming a part of this culture over time. Queen Christina is one of the famous personality whom has involved in popular culture with her many features (gender, appereance, personality etc. ).

Queen Christina is located in the popular culture by many different ways; as novel character (Cleobuline), as subject of works of art (oil painting, photography), as woman to whom cultural and sports activities dedicated (Queen Christina Nations Cup, 7th Roman Carnival 2015), as founder of the world's oldest newspaper (The Post och Inrikes Tidningar), as subject of commemorative stamps (300 years of the Finnish Postal System and the 350th Anniversary of the University of Helsinki).

According to literature review this study shows that Queen Christina's contribution to popular culture is not limited only with her geography. It seems to spread a wide area including America (in Hollywood with Garbo's film called "Queen Christina etc. ) and Europe (in Finland with post stamps, in Italy with 7th edition of Roman Carnival etc. ). Also this contribution is recognized in other parts of the world by the other popular culture products like; books (Queen Christina of Sweden" (Hardinge, 1880), "Queen Christina" (Masson, 1974), "Outrageous Queen: Biography of Christina of Sweden" (Cartland, 1974), "Christina Queen of Sweden: The Restless Life of a European Eccentric" (Buckley, 2005), "Kristina: The Girl King, Sweden, 1638 (The Royal Diaries)" (Meyer, 2003), "Queen Christina of Sweden (Queens and Princesses)" (Mattern, 2009) etc. ) which are written on Queen Christina and accessories like watches, brooches on which her portraits are used and newspaper which is the oldest one of the world (also which has transformed as a web service since 1 January 2007 with the name of Posttidningen and Inrikes Tidningar by Bolagsverket). Especially, her gender through her clothes, her attitude, her love relationships and her intellectual experience/contribution are emerging as the aspects which mainly discussed in popular culture. In this respect, it can be said that Queen Christina has great impact on popular culture. This impact has continued it's presence from her century till today. Consequently, Queen Christina seems to be a sophisticated woman and an extraordinary leader who has been prevailing beyond her century.

\section{References}

Bakhtin, M. (2001). Karnavaldan Romana Edebiyat Teorisinden Dil Felsefesine Seçme Yazılar, Cem Soydemir (translator), İstanbul: Ayrıntı Yayınları.

Barron, L. (2012). Social Theory in Popular Culture, Palgrave Macmillan.

Betts, R. F. (2004). A History Of Popular Culture: More of Everything, Faster and Brighter, Routledge.

Boyle, R. \& Haynes, R. (2009). Power Play: Sport, the Media and Popular Culture, Edinburgh University Press.

Brzezinski, R. (2004). The Army Of Gustavus Adolphus (1): Infantry, Osprey Publishing.

Browning, R. (2007). The Complete Works Of Robert Browning: Volume XV, with Variant Readings and Annotations, Allan C. Dooley \& David Ewbank (ed. ), Ohio University Press.

Buckley, V. (2005). Christina Queen of Sweden: The Restless Life of a European Eccentric, HarperPerennial.

Bullogh, V. L. (1993), Cross Dressing, Sex and Gender, University of Pennsylvania Press.

Cavendish, R. (2004). "Abdication of Queen Christna of Sweden", History Today, Jun, pp. 54.

Cartland, B. (1974). Outrageous Queen: Biography of Christina of Sweden, Corgi Childrens.

Child, J. (2005). "The Politics and Semiotics of the Smallest Icons of Popular Culture: Latin American Postage Stamps", Latin American Research Review, Vol. 40, No. 1, pp. 108-137.

Danesi, M. (2008). Popular Culture: Introductory Perspectives, USA: Rowman \&Littlefield Publishers, Inc.

Dumas, A. (1830). Stockholm, Fontainbleau et Rome: trilogie dramatique sur la vie de Christine, cinq actes en vers avec prologue et epilogue, Barba.

Erdoğan, I. \& Alemdar, K. (2005). Popüler Kültür ve Illetişim, Ankara: ERK.

Haskell, F. (1966). "'Christina Queen of Sweden' and Some Related Publications", The Burlington Magazine, Vol. 108, No. 763, pp. 494499

Hardinge, H. A. (1880). Queen Christina of Sweden, University of Michigan Library.

Gans, H. (2008). Popular Culture and High Culture: An Analysis and Evaluation Of Taste, USA: Basic Books.

Goes, F. J. (2013). The Eye in History, Jaypee Brothers Medical Publishers Inc.

Lucca, V. D. (2010). "Strategies of women patrons of music and theatre in Rome: Maria Mancini Colonna, Queen Christina of Sweden, and women of their circles", Renaissance Studies, Vol. 25 No. 3, pp. 374-392.

Masson, G. (1974). Queen Christina, Cardinal; New ED edition.

Mattern, J. (2009). Queen Christina of Sweden (Queens and Princesses), Capstone Press. 
Meyer, C. (2003). Kristina: The Girl King, Sweden, 1638 (The Royal Diaries), Scholastic.

Mutlu, E. (2006). "Popüler Kültürü Eleştirmek", Doğu Batı, Ankara: Doğu Batı Yayınları, pp. 11-42.

Nivre, E. (2010). " "An affair of great importance"-Queen Christina of Sweden (1626-1689)", Comunicação \& Cultura, n. ${ }^{\circ}$ 9, pp. 43-58.

Scobbie, I. (2006). Historical Dictionary of Sweden, Scarecrow Press, Inc.

Storey, J. (2009). Cultural Theory and Popular Culture: An Introduction, Pearson Longman.

Waters, S. (1994). " 'A Girton Girl on a Throne': Queen Christina and Versions of Lesbianism, 1906-1933", Feminist Review, No. 46, Sexualities: Challenge\&Change, pp. 41-60.

Weaver, J. A. (2009). Popular Culture Primer, Peter Lang Publishing.

Wolthers, L. (2013). "Punctuating the Nation's Narratives: History Painting and Performativity", Performing Memory in Art and Popular Culture, Liedeke Plate, Anneke Smelik (Ed. ), Routledge, pp. 155-169.

\section{Internet References}

http: //www. iep. utm. edu/wasa/, Access: 20. 02. 2015

http: //www. iep. utm. edu/wasa/\#H1, Access: 10. 02. 2015

http: //www. sciencemuseum. org. uk/broughttolife/people/paracelsus. aspx, Access: 27. 02. 2015

http: //queenchristina. eu/the-qc-project/, Access: 27. 02. 2015

http: //old. portmadisonyc. org/wp-content/uploads/2010/09/qcnc-story. pdf, Access: 27. 02. 2015

http: //plato. stanford. edu/entries/madeleine-scudery/\#Wor, Access: 28. 02. 2015

https: //alexiasinclair. com/about, Access: 26. 02. 2015

https: //alexiasinclair. com/collections/the-regal-twelve\#christina-of-sweden-description, Access: 26. 02.2015

http: //www. unisa. edu. au/global/samstag/exhibitions/2009/documents/alexiasinclair_roomnotes. pdf, Access: 25. 02. 2015

http: //www. idnworld. com/creators/?id=AlexiaSinclair, Access: 26. 02. 2015

http: //6mr. fi/queen-christina-nations-cup, Access: 25. 02. 2015

http: //www. buzzinrome. com/2015/02/06/rome-dedicates-the-2015-carnival-to-christina-queen-of-sweden/, Access: 25. 02. 2015

http: //www. romecentral. com/carnevale-romano-2015-roma-sfilate-e-feste-maschera/?lang=en, Access: 25. 02. 2015

http: //www. nytimes. com/movie/review?res=9802E1D91531E333A25754C2A9649D946294D6CF, Access: 26. 02. 2015

http: //www. theguardian. com/film/2008/sep/03/greatgarbo, Access: 10. 02. 2015

http: //www. amazon. com/Christina-Original-Poster-Rouben-Mamoulian/dp/B008SEI4LW, Access: 24. 02.2015

http: //www. washingtontimes. com/news/2007/jan/28/20070128-104107-2575r/). , Access: 10. 02. 2015

http: //www. vam. ac. uk/blog/creating-new-europe-1600-1800-galleries/born-on-this-day-queen-christina-of-sweden, Access: 10. 02. 2015

http: //d43fweuh3sg51. cloudfront. net/media/media_files/266947. JPG, Access: 10. 02. 2015

http: I/www. zazzle. co. uk/queen_christina_of_sweden_sebastien_bourdon-256472459292786633, Access: 10. 02.2015

http: //www. zazzle. co. uk/queen_christina_of_sweden_1652_pinback_button-145086113147726152, Access: 10. 02. 2015

http: //royalwomen. tripod. com/id4. html, Access: 10. 02.2015

https: //philosophynow. org/issues/64/Pop_Culture_An_Overview, Access: 01. 02. 2015

http: //en. museicapitolini. org/mostre_ed_eventi/mostre/lux_in_arcana_I_archivio_segreto_vaticano_si_rivela, Access: 10. 02. 2015

http: //www. artamene. org/, Access: 01. 02. 2015

http: //www. telegraph. co. uk/news/worldnews/europe/vaticancityandholysee/9111168/Vatican-Secret-Archives-reveal-abdication-letterof-hermaphrodite-Swedish-queen. html, Access: 10. 02. 2015

http: //www. numismatas. com/Forum/Pdf/David\%20Ruckser/Coins\%20of\%20Sweden. pdf, Access: 02. 02. 2015

https: //poit. bolagsverket. se/poit/PublikOmTjansten. do?method=redirect\&forward=main. omtjansten. inenglish, Access: 02. 02. 2015

http: //global. britannica. com/EBchecked/topic/75794/Sebastien-Bourdon, Access: 10. 02. 2015

\section{Footnotes}

2. She, later known as Maria Christina Alexandra occasionaly Countess Dohna, Received from: http: //www. numismatas. com/Forum/Pdf/David\%20Ruckser/Coins\%20of\%20Sweden. pdf.

3. Theophrastus Aureolus Bombastus von Hohenheim (1493-1541) who changed his name to Paracelsus ('equal to Celsus') was the Swiss Physician and Alchemist,

Received from: http: //www. sciencemuseum. org. uk/broughttolife/people/paracelsus. aspx.

4. Sébastien Bourdon (1616-1671) was a French painter. In 1652 he became the chief painter of Queen Christina, who posed him several times, Received from: http: //global. britannica. com/EBchecked/topic/75794/Sebastien-Bourdon 